\title{
Quantification of groundwater-surface water interactions using environmental isotopes: A case study of Bringi Watershed, Kashmir Himalayas, India
}

\author{
Nadeem A Bhat* and Gh Jeelani \\ Department of Earth Sciences, University of Kashmir, Srinagar 190 006, India. \\ *Corresponding author. e-mail: mnadeem83@gmail.com
}

MS received 31 October 2016; revised 13 July 2017; accepted 28 November 2017; published online 25 June 2018

Environmental isotopes including $\delta^{18} \mathrm{O}, \delta^{2} \mathrm{H}$ and ${ }^{3} \mathrm{H}$ of precipitation, streams and springs were determined in the mountainous Bringi catchment of Kashmir Himalaya, dominated by carbonate lithology. The isotopic signature of winter precipitation is reflected in stream and spring water in late spring and is, therefore, representative of snow melting. The spring waters in September bear the enriched isotopic signatures of summer rainfall. The strong correlation $\left(r^{2}=0.97\right)$ between the isotopic composition of streams and springs indicates the streams and springs either share similar catchments or the springs are recharged by the streams. Chloride mass balance and isotopic mass balance studies suggest that the surface recharge component averages $337.35 \mathrm{~m}^{3} / \mathrm{s}$, which is about $75 \%$ of total stream discharge during the high flow period. Similarly, the contribution of surface water to groundwater recharge during the low flow period averages $7.5 \mathrm{~m}^{3} / \mathrm{s}$, which is about $18.6 \%$ of total stream flow. Furthermore, the mean residence time of the springs calculated from the tritium decay equation is very short ( $<1$ year). The residence time is longer for Kongamnag and short for Achabalnag, which is further supported by dye testing.

Keywords. Environmental isotopes; groundwater-surface water interaction; Bringi watershed; Kashmir Himalayas; India.

\section{Introduction}

Karst aquifers are becoming an increasingly important source of water supply in many parts of the world as it is estimated that $25 \%$ global population depends on karst water supplies (Ford and Williams 1989). However, karst geo-ecosystem being highly fragile and sensitive, are suffering progressive degradation by human activities (Jeelani et al. 2011). Urbanization, industrialization, deforestation, etc., have transformed, disturbed and partially or totally destroyed the karst landscape causing modification of drainage and deterioration in the quality of groundwater. Due to lack in effective attenuation mechanisms in karst systems, the breakdown of contaminants by micro-organisms and by physical and chemical processes is very weak (Ford and Williams 1989). Thus, any contamination in either of the sources can lead to the deterioration of water quality of both surface and groundwater. One of the important features of karst terrains is the interaction between surface water and groundwater, which has been the subject of interest for many researchers because of 


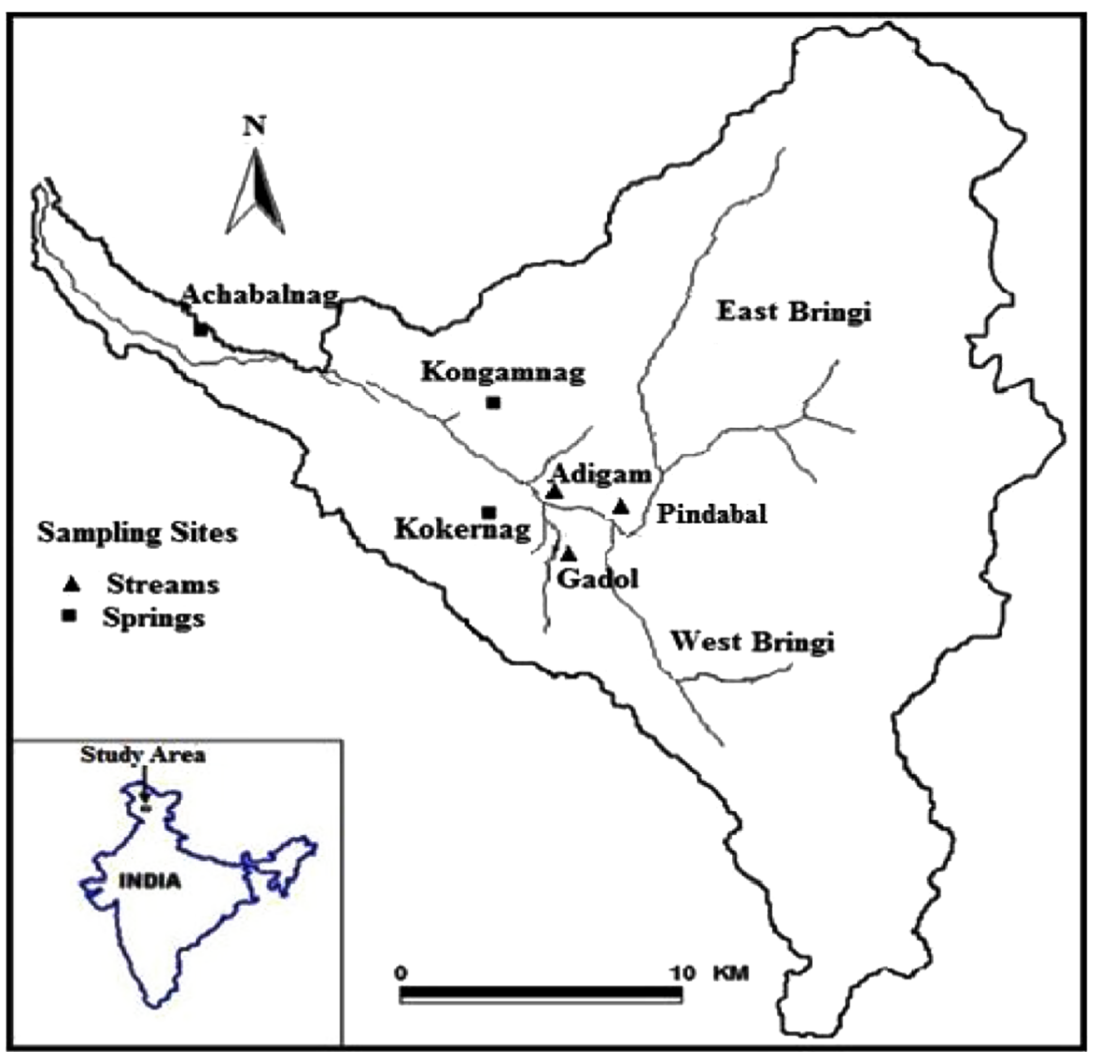

Figure 1. Location map of the Bringi watershed showing sampling sites.

the potential of contamination of the aquifer from surface water recharge. A number of approaches are available to study such processes in karst terrains (Gat 1971; Ford and Williams 1989; Agarwal et al. 2006). However, environmental isotopes in conjunction with convectional hydro-geochemistry have been used by several workers (Barker and Horton 1936; Clark and Fritz 1997; Kendall and Mcdonnell 1998; Rao 2006). The signature of recharge from losing streams in karst aquifers has been traced over distances of several kilometers using these stable isotopes (Greene 1997). Differences between the composition of the water isotopes $\left(\delta^{18} \mathrm{O}\right.$ and $\left.\delta \mathrm{D}\right)$ in rainfall, stream runoff and groundwater are used to quantify mixing of groundwater and surface water. Similarly, Chloride and isotopic mass balance equations have been used to determine the mechanism and components of groundwater recharge (Eriksson 1958; Eriksson and Khunakasem 1969; Datta et al. 1973; Edmunds and Walton 1980; Sharma and Hughes 1985; Jhonston 1987; Houston 1988; Navada and Rao 1991; Wood and Sanford 1995; Sami and Hughes 1996; Cook et al. 2001; Shivanna et al. 2004; Bajjali 2006; Jeelani 2007).

\section{Description of the study area}

Bringi catchment is one of the main upland catchments of River Jhelum, lies towards the south-east of Kashmir Valley in Western Himalayas between latitudes $33^{\circ} 20^{\prime}-33^{\circ} 45^{\prime} \mathrm{N}$ and longitudes $75^{\circ} 10^{\prime}$ $75^{\circ} 30^{\prime} \mathrm{E}$ (figure 1) and covers an area of $595 \mathrm{~km}^{2}$. The elevation of the mountainous catchment ranges from $1650 \mathrm{~m}$ (amsl) at Achabal town to more than $4000 \mathrm{~m}$ (amsl) near Sinthan top. The Bringi watershed is drained out by Bringi stream, which is fed by a number of tributaries of which the most important are east and west Bringi. The streams are mostly fed by seasonal snow melt, which generally lasts up to August and September. The Bringi stream enter river Jhelum at Anantnag.

The area has a temperate climate, characterized by marked seasonality with four well developed seasons namely spring, summer, autumn and winter (Hussain 2005). Dramatic variations in weather witnessed within the valley are largely owing to the variations in the altitude and aspect (Necve 1933). Average monthly temperature and average monthly precipitation of the Kokernag station for the last two decades from January 1990 to 


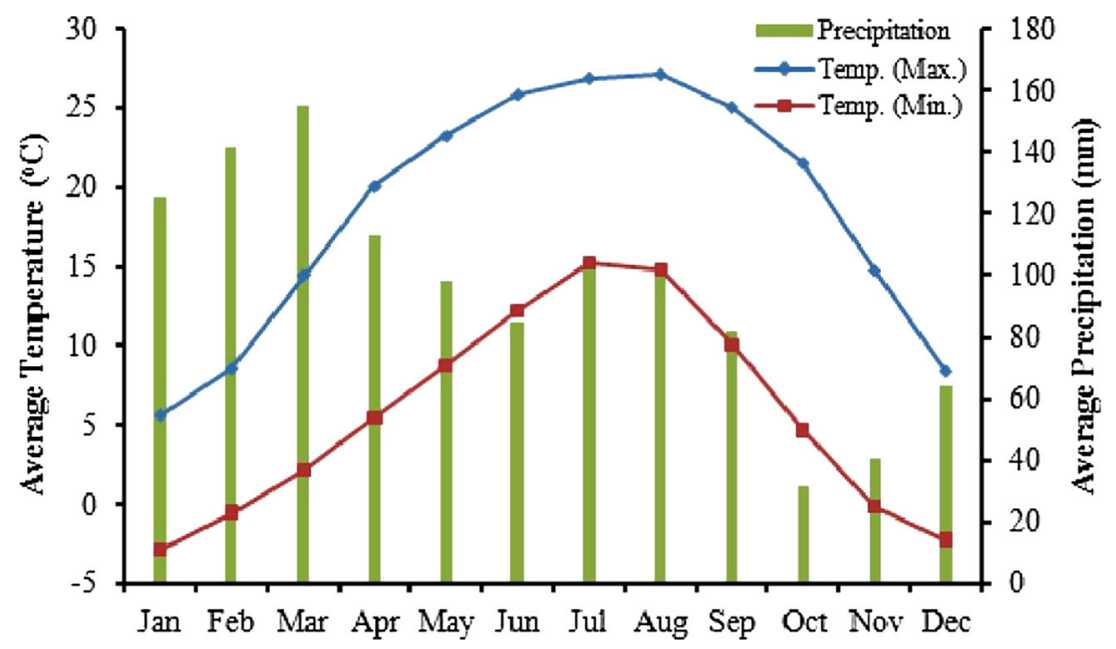

Figure 2. Average monthly variation of temperature and precipitation for last two decades from 1990 to 2009 (blue curve is maximum temperature, red curve is minimum temperature and green bars are precipitation).

Table 1. Bimonthly data of temperature, precipitation and stream discharge of Bringi Watershed.

\begin{tabular}{llcccccc}
\hline Station & \multicolumn{1}{c}{ Parameters } & Mar-08 & May-08 & Jul-08 & Sep-08 & Nov-08 & Jan-09 \\
\hline Kokernag & Temperature $\left({ }^{\circ} \mathrm{C}\right)$ & 18.3 & 23.6 & 27.3 & 25.4 & 16.1 & 5 \\
Kokernag & Precipitation & 25.8 & 134.7 & 62.4 & 107 & 9.9 & 195 \\
Pindabal & Stream discharge $\left(\mathrm{m}^{3} / \mathrm{s}\right)$ & 321 & 633 & 719 & 470 & 220 & 124 \\
Adigam & & 95 & 170 & 266 & 133 & 58 & 57 \\
\hline
\end{tabular}

December 2009 are shown in figure 2. Average precipitation of the last two decades from 1990 to 2009 revealed that March is the rainiest month (mean monthly precipitation $\sim 155 \mathrm{~mm}$ ) and October the driest (mean monthly precipitation $\sim 40 \mathrm{~mm}$ ). However, during the period of study, January received the maximum precipitation (195 mm) and November the minimum (9.9 mm) (table 1). During winter, snow is accumulated at higher altitudes (>2500 $\mathrm{m}$ amsl) and shadow zones within the valleys when the mean temperature remains subzero.

The Bringi watershed has diverse geology, ranging in age from Paleozoic to Recent, with Panjal Traps and Triassic Limestone as the dominant formations of hydrological importance (Middlemiss 1910; Wadia 1975; GSI 2012). The limestone is by no means pure and contains 15 to $90 \%$ dolomite (Coward et al. 1975). Karewas are the fluvio-lacustrine deposits that overlie the limestone and contain unconsolidated material including light grey sands, dark grey clays, coarse to fine grained sand, gravel, marl, silt, varved clays, brown loam lignite, etc. (Bhat 1975). The alluvial deposits represent recent sediments and contain fine silt and mud, though active flood plains are mainly of coarse gravel and boulders (Jeelani 2004).

The springs of the Bringi catchment emerge from carbonate rocks of Triassic age along the foothills of Pir-Panjal range. Geologically young carbonate rocks have porosities that range from $2 \%$ for coarse limestone to more than $50 \%$ for indurate chalk. The primary permeability of old unfractured limestone and dolomite is commonly less than $10^{-7} \mathrm{~m} / \mathrm{s}$ at near surface temperature. However, the Triassic limestone of the study area is highly cavernous with hydraulic conductivity up to $1000 \mathrm{~m} /$ day (Jeelani 2008). It is likely that water moves predominantly along bedding planes and so the water rises from the depth and no extensive vadose cave is present immediately behind any of the springs. The springs are at the lowest hydrological points of the limestone block, which suggests that the limestone-groundwater is well integrated (Jeelani 2007). A few springs discharge from Karewas, which are not productive aquifers. Due to low hydraulic conductivity, alluvium and Karewa sediments block the water flowing through the Triassic limestone and the water appears in the form of spring at the contact between Alluvium or Karewas and Triassic limestone. 


\section{Methodology}

Water samples from precipitation, snow melt, streams and springs were collected for $\delta^{18} \mathrm{O}, \delta^{2} \mathrm{H}$ and Tritium on a bimonthly basis from March 2008 to January 2009 across the Bringi watershed. The samples were collected following standard procedures (Clark and Fritz 1997; APHA 1998; Goldscheider and Drew 2007). For stable isotope $\left(\delta^{2} \mathrm{H}\right.$ and $\left.\delta^{18} \mathrm{O}\right)$ analysis, 18 precipitation samples, 6 stream water samples and 18 spring water samples were collected from the study area. Precipitation samples were collected in home-made precipitation collectors, installed at many selected sites across the study area. Each collector consisted of a 20-L plastic container fitted with a funnel and a long narrow tube to avoid evaporation (Jeelani et al. 2010). The samples were immediately poured into a $125 \mathrm{ml}$ HDPE bottles with gas tight caps. Stream water samples were collected above the confluence of the streams and spring water samples were collected at the source. The samples were collected by dipping bottles into the water body directly and sealing immediately afterwards. For Tritium, 3 precipitation, 1 stream and 3 spring samples were collected in $1 \mathrm{~L}$ HDPE bottles.

Chloride was determined by titration with $\mathrm{AgNO}_{3}(0.02 \mathrm{~N})$ using potassium chromate (5\%) as an indicator (APHA 2005). The chloride concentration in the water samples was analysed for mass balance studies. The contribution of precipitation to groundwater has been calculated by a number of researchers using Chloride Mass Balance Equation (Eriksson and Khunakasem 1969; Jhonston 1987; Houston 1988; Wood and Sanford 1995; Sami and Hughes 1996; Cook et al. 2001; Bajjali 2006; Jeelani 2007).

$$
\begin{aligned}
& \operatorname{Recharge}_{(\mathrm{mm})} \\
& \quad=\operatorname{Rainfall}_{(\mathrm{mm})} * C_{\text {Rainfall }} / C_{\text {Spring water }}
\end{aligned}
$$

where $C$ is the concentration of chloride in rainfall and spring water.

Deuterium analyses were carried out using a dual-inlet isotope ratio mass spectrometer (Isoprime with Masslynx software Ver. 4.0) at the National Institute of Hydrology (NIH), Roorkee. Oxygen-18 analysis was carried out at Isotope Application Division, Bhaba Atomic Research Centre (BARC), Mumbai, using Isotope Ratio Mass Spectrometer (Geo 20-20, Europa) by gas equilibration method (Epstein and Mayeda 1953). The results are reported as $\delta$ (delta) values (Craig 1961) representing per mil deviation from the V-SMOW standard (Vienna Standard Mean Ocean Water) (Gonfiantini 1981). The precision of the measurement was $\pm 0.1 \%$.

For isotopic mass balance studies involving a two-component mixture, the fraction of surface water (YS) in the mixture is defined as (Clark and Fritz 1997; Mook 2006)

$$
\begin{aligned}
& Y_{G}+Y_{S}=Y_{M} \\
& Y_{G} \delta_{G}+Y_{S} \delta_{S}=Y_{M} \delta_{M}
\end{aligned}
$$

where $Y_{G}$ and $Y_{S}$ are the percentage contribution of groundwater and surface water to the mixture $Y_{M} \cdot \delta_{G}, \delta_{S}$, and $\delta_{M}$ are the isotopic composition of groundwater, surface water and admixture respectively. Substituting equation (2) in (3) for $Y_{G}$, provides the contribution of surface water component $Y_{S}$ to the groundwater mixture.

$$
Y_{S}=Y_{M}\left(\delta_{M}-\delta_{G}\right) /\left(\delta_{S}-\delta_{G}\right) .
$$

Differences in the isotopic composition of surface water, rainfall, and groundwater result in relatively high precision for detecting the mixing proportion of surface water in groundwater (Katz et al. 1997).

Tritium analysis was carried out at Hospital Laboratory, Bhabha Atomic Research Centre (BARC), Mumbai, using a Liquid Scintillation Counter (Quantulus Model No. 1220 - PerkinElmer make) after electrolytic enrichment of samples in tritium. The accuracy of the tritium measurement was $0.5 \mathrm{TU}(1 \sigma)$. The residence time of the groundwater calculated from the decay of tritium is based on the assumption that the tritium input into the groundwater is known and that the residual tritium measured in groundwater is the result of decay alone (Clark and Fritz 1997). According to the decay equation

$$
a_{t}^{3} H=a_{o}^{3} H e^{-\lambda t}
$$

where $a_{o}^{3} H$ is the initial tritium activity or concentration in precipitation (expressed in TU) and $a_{t}^{3} H$ is the residual activity (measured in groundwater) remaining after decay over time $t$. The decay term $\lambda$ is equal to $\ln 2$ divided by half life $t 1 / 2$.

Spring discharge was calculated by the velocity area method (Fetter 1980; Chow et al. 1988; Goldscheider and Drew 2007). The discharge through any given cross-section of a stream or spring was estimated by determining the cross-sectional 
area of flow and the average velocity of flow of water (Freeze and Cherry 1979; Fetter 1980; Chow et al. 1988). In addition, ambient temperature, precipitation and stream discharge data were also used in the present study. Temperature and precipitation data of the Kokernag station was collected from the India Meteorological Department, Srinagar. Discharge data of Bringi stream was collected from P\&D Department, Srinagar.

\section{Results}

\subsection{Isotopes in precipitation}

Stable isotopes in precipitation of the study area (rainwater and fresh snow) showed a wide spatial and temporal variability (table 2). The isotopic composition of precipitation ranged from -2.044 to $-11.26^{\circ} \%$ with a mean of $-6.03 \%$ for $\delta^{18} \mathrm{O}$ and -7.59 to $-46.41 \%$ with a mean value of $-36.63 \%$ for $\delta^{2} \mathrm{H}$. Highest depleted values were observed at Pindabal during January and most enriched values were observed at Achabal during July. The isotopes in precipitation at Achabal station was enriched $\left(\right.$ Mean $=-5.44 \%$ for $\delta^{18} \mathrm{O}$ and $-20.71 \%$ for $\left.\delta^{2} \mathrm{H}\right)$ as compared to Kokernag (Mean $=-5.99 \%$ for $\delta^{18} \mathrm{O}$ and $-23.02^{\circ} \%$ for $\delta^{2} \mathrm{H}$ ) and Pindabal (Mean $=-6.65 \%$ for $\delta^{18} \mathrm{O}$ and $-25.61 \%$ for $\left.\delta^{2} \mathrm{H}\right)$ precipitation sites. The variability of isotopes from one site to another is a function of several factors including storm-track origin, rainfall amount and intensity, altitude, atmospheric temperature and number of evaporation and condensation cycles (Dansgaard 1964; Gonfiantini et al. 1976; Rozanski et al. 1993; Gat et al. 1996; Sidle 1998; Longinelli and Selmo 2003; Vreča et al. 2006; Price et al. 2008).

Stable isotopes in precipitation show depleted values during low temperatures and enriched values during higher temperatures (figure 3). The plot of $\delta^{18} \mathrm{O}$ in precipitation against precipitation amount also showed that the isotopic composition of precipitation is dominantly controlled by the temperature, with the exception of during September (figure 3), in which high precipitation $(\sim 107 \mathrm{~mm})$ resulted in depleted values (amount effect). The samples were depleted during January with a mean value of $-10.63 \%$ for $\delta^{18} \mathrm{O}$ and $-43.85 \%$ for $\delta^{2} \mathrm{H}$ and enriched during July at an average of $-2.34 \%$ for $\delta^{18} \mathrm{O}$ and $-8.96 \%$ for $\delta^{2} \mathrm{H}$. Enriched values during July are due to the high atmospheric temperatures. However, sub-zero

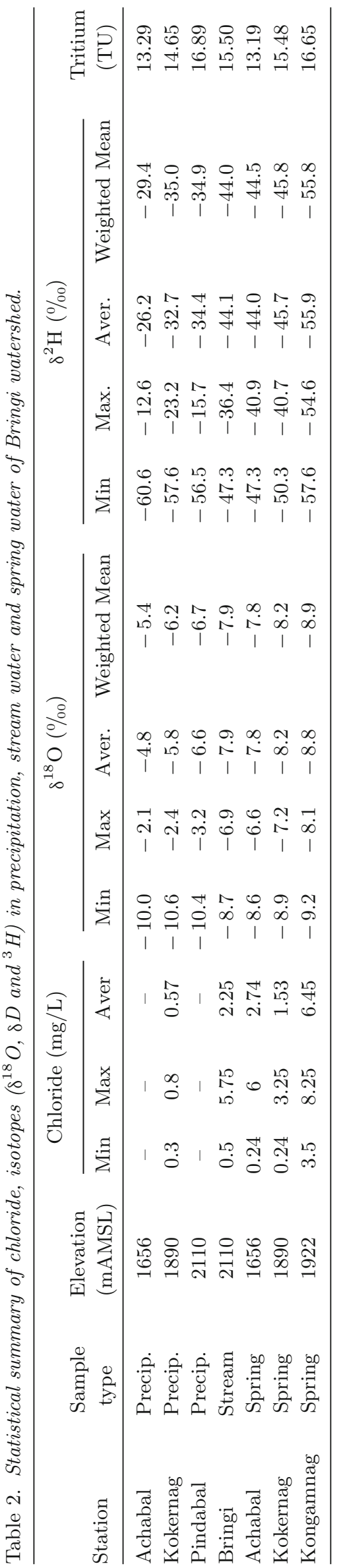




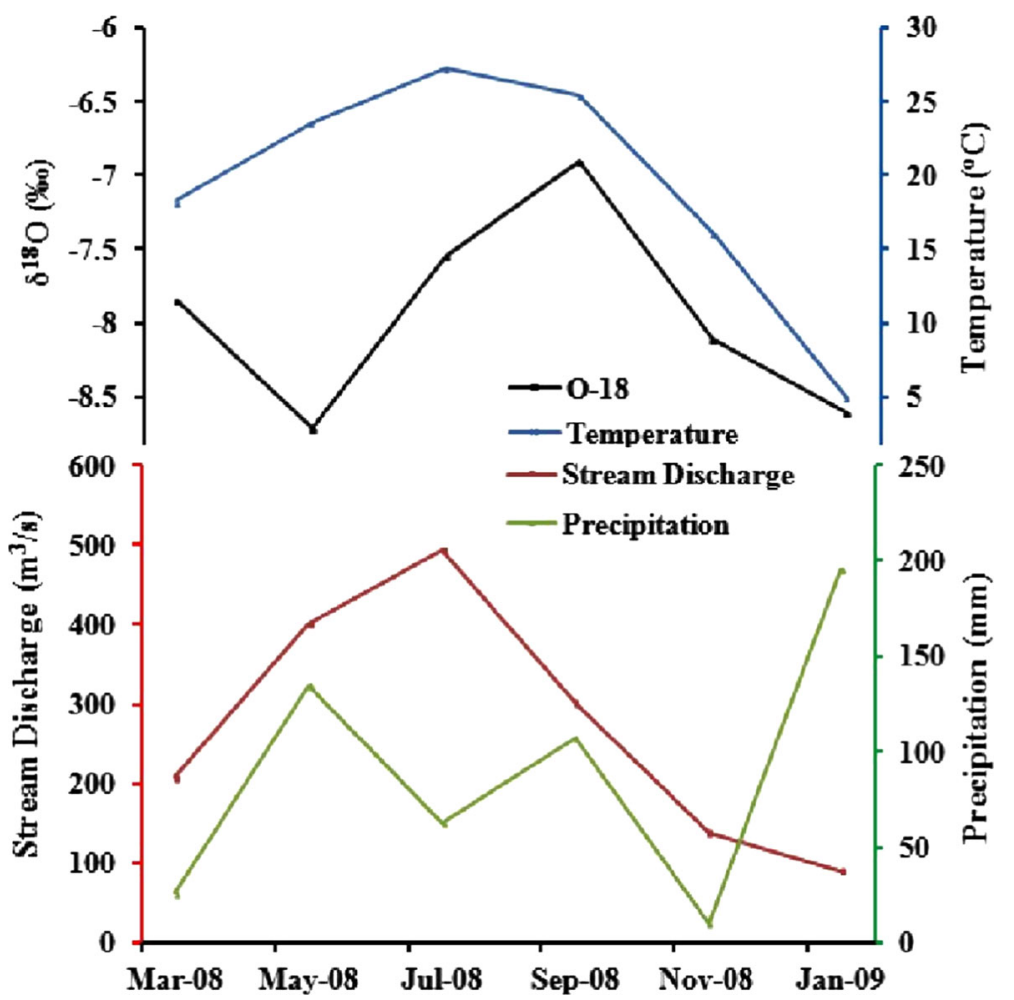

Figure 3. Variation of $\delta^{18} \mathrm{O}$, temperature, precipitation and stream discharge.

temperature coupled with high amount of precipitation during January makes the precipitation more depleted. Depleted isotopic composition with lesser variability and positive correlation with temperature during January, March and May $(-0.6$ to $1.2 \%$ for $\delta^{18} \mathrm{O}$ and -1.1 to $-2.2 \%$ for $\left.\delta^{2} \mathrm{H}\right)$ is attributed to the single source of moisture brought by westerly winds from Central Asia through Mongolia. However, the more variability $(-2.6 \%$ to $-3.6 \%$ for $\delta^{18} \mathrm{O}$ and $-3.07 \%$ to $-6.7 \%$ for $\left.\delta^{2} \mathrm{H}\right)$ and anomalous behaviour of the isotopes during July, September and November, reflected the local sources of precipitation in addition to the moisture brought by the western disturbances. Despite these peculiarities, the distribution of the isotopic composition in the study area is dominantly controlled by the elevation. The altitude effect obtained from the weighted mean $\delta^{18} \mathrm{O}$ and elevation data of precipitation resulted a depletion of $-0.5 \%$ oo per $100 \mathrm{~m}$ rise in elevation. The deuterium excess parameter $(d)$ defined as $\delta^{2} \mathrm{H}-8 * \delta^{18} \mathrm{O}$ for the precipitation samples ranged from 8.76 to $47.67 \%$ at an average of $25.35 \%$, the lower value was observed in precipitation collected during summer particularly July 2008 and higher value in winter particularly January 2009 (Jeelani et al. 2014). The d-values of precipitation all along the path of western disturbances (Iran, Afghanistan, Pakistan and Kashmir) are high (Yurtsever and Gat 1981; Rozanski et al. 1993), which confirms that an increase of deuterium excess was correlated with seasonal bias of precipitation towards winter. The lower values during summer could be partly due to contribution of moisture from evaporation of local water bodies including snow and glaciers, lakes and other surface water bodies (figure 4).

\subsection{Isotopes in streams}

The stable isotope composition of the stream waters, collected from one station (table 2), showed a very narrow temporal variation, ranging from -6.85 to $-8.68 \%$ with a mean of $-7.87 \%$ for $\delta^{18} \mathrm{O}$ and -40.82 to $-48.09^{\%}$ on with a mean value of $-44.08 \%$ for $\delta^{2} \mathrm{H}$. The streams were depleted during May and January ( -8.66 to $-8.68 \%$ for $\delta^{18} \mathrm{O}$ and -48.09 to $-48.97 \%$ for $\left.\delta^{2} \mathrm{H}\right)$ and were enriched during July and September $(-6.85$ to $-7.49 \%$ for $\delta^{18} \mathrm{O}$ and -40.82 to $-40.97 \%$ for $\left.\delta^{2} \mathrm{H}\right)$. The temporal variability of isotopes found in the precipitation is not reflected in the isotopic composition of streams. The streams were depleted in May also, indicating the indirect role of precipitation in controlling stream flows. The melting of snow and ice accumulated during the preceding winter at higher altitudes dominantly 


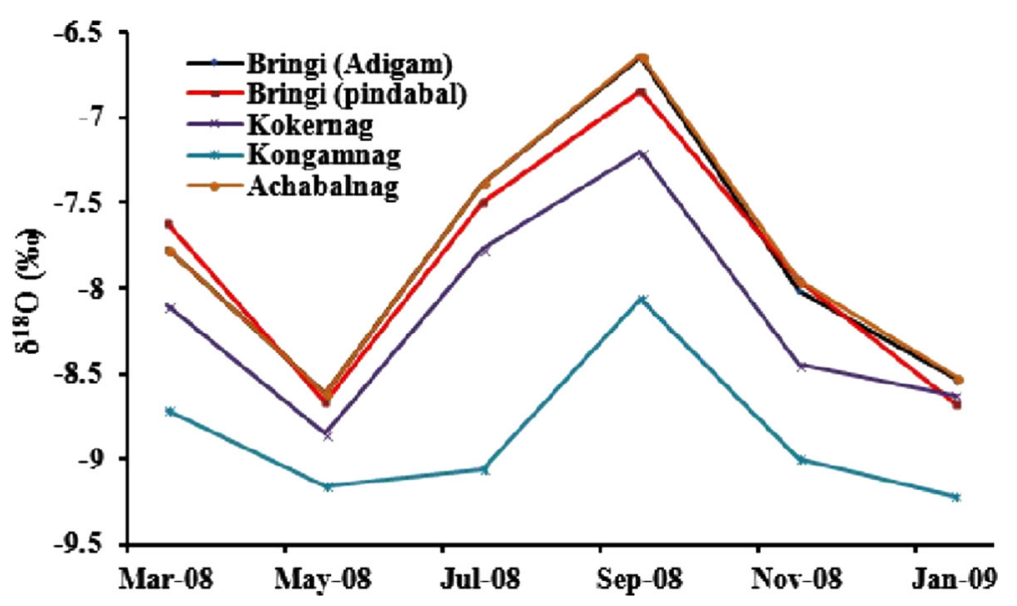

Figure 4. Positive temporal variation of $\delta^{18} \mathrm{O}$ of springs with streams of Bringi watershed.

control the stream flow in May, which in turn resulted in depleted $\delta^{18} \mathrm{O}$ values in stream water. Keeping in mind the lower temperatures and negligible melting of snow in January, the $\delta^{18} \mathrm{O}$ signature of stream flow in January is representative of the base flow, mostly provided by the aquifer and/or surface reservoirs. As most of the snow is exhausted before summer, the isotopically enriched stream water during July and September is mostly controlled by atmospheric temperature. During September, the recorded rainfall and its isotopic composition were $107 \mathrm{~mm}$ and $-6.85 \%$ for $\delta^{18} \mathrm{O}$ and $-40.97^{\circ} \%$ for $\delta^{2} \mathrm{H}$, respectively. Therefore, the enriched stream flow during September is representative of rainfall. The d-excess values of stream water samples ranged from 16.66 to $19.89^{\circ} \%$ with an average of $18.13 \%$, where the highest value was observed during May 2008 and the lowest value in September 2008. The higher d-excess value during May is due to the melting of snow and ice of the preceding winter which contributed depleted waters into streams. However, lower dexcess values in streams during September may therefore be the result of high amount of local precipitation.

\subsection{Isotopes in springs}

The discharge of the springs is highly variable ranging from 10 to $3400 \mathrm{~L} / \mathrm{s}$. Annual average discharge was highest in Kokernag at an average of $2050 \mathrm{~L} / \mathrm{s}$ and lowest in Kongamnag averaging at $11 \mathrm{~L} / \mathrm{s}$. Seasonally, the average discharges of springs are maximum in July $(\sim 1830 \mathrm{~L} / \mathrm{s})$ and minimum in January $(\sim 550 \mathrm{~L} / \mathrm{s})$.
The stable isotope composition of springs showed a narrow range varying from -6.64 to $-9.223 \%$ with a mean of $-8.28 \%$ for $\delta^{18} \mathrm{O}$ and -40.93 to $-57.59 \%$ with a mean value of $-48.40 \%$ for $\delta^{2} \mathrm{H}$. Kongamnag, the highest elevation spring, showed the most depleted values at an average value of $-8.87^{\circ}$ oo for $\delta^{18} \mathrm{O}$ and $-55.57^{\%}$ oo for $\delta^{2} \mathrm{H}$. The lowest elevation spring, Achabalnag, exhibits enriched isotopes at an average value of $-7.81^{\circ} \%$ for $\delta^{18} \mathrm{O}$ and $-43.76 \%$ for $\delta^{2} \mathrm{H}$ (table 2 ). The annual amplitude of isotopic variations in springs was 1.16 to 1.97 for $\delta^{18} \mathrm{O}$, which is quite similar to the Figeh and Kapuz karst springs (Kattan 1997) and Karst springs of Meramec River basin (Fredrickson and Criss 1999), where the amplitude was about $1 \%$. The Karst springs show distinct isotopic signatures, reflecting different sources of recharge and there is a little or no interconnection within the aquifer.

Temporally, the spring waters were most depleted in stable isotopes during May with a mean value of $-8.87 \%$ for $\delta^{18} \mathrm{O}$ and $-51.03 \%$ for $\delta^{2} \mathrm{H}$ and least depleted in September with a mean value of $-7.3 \%$ for $\delta^{18} \mathrm{O}$ and $-45.39 \%$ for $\delta^{2} \mathrm{H}$. The most depleted values were recorded about 3 months after the lowest temperature and the least depleted values were recorded about 2 months after the maximum temperature. The isotopic signature in May is therefore representative of snow melting, while the isotopic signature during September is representative of rainfall. Stable isotopic signature in January represents base flow. Similarly, d-excess in springs ranged from 8.93 to 26.7 at an average of 17.4, the lower value corresponds to Kongamnag during September 2008 and higher value to Achabalnag during January 2009. 


\section{Discussion}

\subsection{Interactions between surface and groundwater}

In temperate climates, generally $2-25 \%$ of precipitation infiltrates to the water table and the rest is lost to runoff, evaporation from soils and transpiration by vegetation (Clark and Fritz 1997). Recharge rates are generally highest when soils are saturated, temperatures are low and vegetation is inactive. Recharge rates are lowest when vegetation is active and significant precipitation is lost to plant transpiration. The mean chloride concentration of rainfall in the study area is $0.57 \mathrm{mg} / \mathrm{L}$ and for that of spring water, it is $3.55 \mathrm{mg} / \mathrm{L}$. The average bimonthly precipitation in the study area during the study period was $90 \mathrm{~mm}$. The estimated recharge using equation (1) is averaged at $16.7 \mathrm{~mm}$, which is about $18.5 \%$ of the total precipitation. The recharge is highly variable during different months, being highest during summer, particularly July (about 22\%) and lowest during winter, particularly November $(<1 \%)$. During summer, high precipitation enhances greater recharge to the springs. However, during November, recharge is at a minimum due to frost action and negligible precipitation.

Although chloride is considered a typical conservative tracer for tracing water movements, the differences between the chloride concentrations in the Bringi stream and springs were very small $(1.2 \mathrm{mg} / \mathrm{L})$, which limits its effectiveness for calculating the stream recharge component to groundwater.

Stable isotope measurements can provide very useful quantitative information about recharge patterns and interactions between groundwater and surface water (Katz et al. 1997). Other chemical and isotopic tracers were used in these studies; however, $\delta^{18} \mathrm{O}$ and $\delta \mathrm{D}$ were the most effective in quantifying mixing between groundwater and surface water (Katz et al. 1995, 1997).

The percentage of surface water that contributes to (and mixes with) groundwater has been computed using steady state Isotopic Mass Balance Equation. Several researchers (Eriksson 1958; Datta et al. 1973; Edmunds and Walton 1980; Sharma and Hughes 1985; Navada and Rao 1991; Shivanna et al. 2004) have used the isotopic technique for evaluating the extent of mixing of river water to groundwater. Stream flow is highest during summer months, particularly May-July and lowest during winter, particularly November to January. The mean $\delta^{18} \mathrm{O}$ composition of groundwater before the high flow period (March 2008) could be taken as $-8.19 \%$ and for surface water during the high flow period (May to July, 2008) was $-8.077^{\circ} \%$. The mean for the admixture of surface and ground water in September was $-7.3 \%$. The surface recharge component, 'YS', calculated using equation (4) yields at $337.35 \mathrm{~m}^{3} / \mathrm{s}$, which is about $75 \%$ of total stream discharge during high flow period. Similarly, for computing the surface water contribution to groundwater recharge during low flow, mean $\delta^{18} \mathrm{O}$ composition of groundwater before low flow conditions (September 2008) was $-7.3 \%$ and for stream water during November 2008 was $-8.1 \%$. The mean $\delta^{18} \mathrm{O}$ composition of admixture in January 2009 was $-8.79 \%$. The contribution of surface water to groundwater recharge during the low flow period averages at $7.5 \mathrm{~m}^{3} / \mathrm{s}$, which is about $18.6 \%$ of total stream flow during low flow period (equation 4). Thus, the spring discharge during summer is the representative of snow melt and the discharge during winter comes mainly from base-flow.

\subsection{Residence time of groundwater}

Tritium concentration of water samples collected from the study area is presented in table 2 . The tritium concentration of precipitation samples collected during March 2008 and June 2008 ranged from 13.29 to $16.89 \mathrm{TU}$ with an average of 15.09 TU. Variation in tritium content of precipitation may be due to the influence of different air masses on precipitation (Warrier et al. 2010). The highest value of tritium was observed in a snow sample collected during March 2008, which may be due to the influence of western disturbances originating from the Mediterranean Sea (Warrier et al. 2010) that bring up snowfall in the valley during winters. The lowest tritium content was found in a rain water sample, collected during June 2008, which may be due to the local atmospheric circulations. Tritium concentration in streams ranged from 14.29 to $16.74 \mathrm{TU}$ at an average of 15.01 TU with higher value being observed during March 2008 and lower value was observed during September. The tritium content of karst springs showed a narrow variation, ranged from 13.2 to $16.65 \mathrm{TU}$ with a mean of 15.1 TU. High tritium was found at Kongamnag collected during March 2008 and low value was observed at Achabalnag collected during March 2008. Higher concentration of tritium at Kongamnag may be due to the longer residence time of water as compared to the other two springs. 
The mean residence time of karst springs calculated from equation (5), in the study area is very short ( $<1$ year). The residence time is longer for Kongamnag and shorter for Achabalnag. These results agree with the tracer tests carried out in Bringi stream at Adigam village (Coward et al. 1972; Bhat 1975). Bromine dye was injected into a sinking stream at Adigam, about $14 \mathrm{~km}$ upstream from Achabalnag. The dye flowed out at Achabalnag within $48 \mathrm{hr}$ with a peak concentration after $68 \mathrm{hr}$. The dye tests confirm the hydrogeological connectivity between injection locations and the springs (Bhat 1975). Monthly or weekly sampling and daily sampling during the peak discharge period is necessary to know the response of the springs to the precipitation events.

\section{Conclusion}

Groundwater recharge was calculated using the Chloride Mass Balance Equation and Isotopic Mass Balance Equation with both methods showing comparable results. The Chloride Mass Balance Equation estimated an average recharge of 16.7 $\mathrm{mm}$, which is about $18.5 \%$ of the total precipitation, being highest during summers (about 22\%) and lowest during winters $(<1 \%)$. During winters, recharge is minimum due to frost action. However, during early summer, high precipitation enhances recharge to the springs. The percentage of surface water that mixes with groundwater was computed using steady state Isotopic Mass Balance Equation. The surface recharge component averages at $337.35 \mathrm{~m}^{3} / \mathrm{s}$, which is about $75 \%$ of total stream discharge during high flow period. Similarly, the contribution of surface water to groundwater recharge during low flow period averages at $7.5 \mathrm{~m}^{3} / \mathrm{s}$, which is about $18.6 \%$ of total stream flow. Further, the mean residence time of the karst springs calculated from the tritium decay equation is very short ( $<1$ year). The residence time is more for Kongamnag and short for Achabalnag, which agrees with previous dye testing.

\section{Acknowledgements}

The authors wish to thank the scientists and staff of Isotope Application Division, BARC Mumbai and NIH Roorkee for mass spectrometric measurements. The financial support from the Board of Research in Nuclear Science, Department of Atomic Energy, Government of India is gratefully acknowledged. The authors are highly indebted to the anonymous reviewers for their valuable scientific comments and suggestions.

\section{References}

Agarwal M, Gupta S K, Deshpande R D and Yadava M G 2006 Helium, radon and radiocarbon studies on a regional aquifer system of the North Gujarat-Cambay region, India; Chem. Geol. 228 209-232.

APHA 1998 Standard methods for the examination of water and waste; American Public Health Association, Washington DC.

Azzaz H, Cherchali M, Meddi M, Houha B, Puig J M and Achachi A 2008 The use of environmental isotopic and hydrochemical tracers to characterize the functioning of karst systems in the Tlemcen Mountains, Northwest Algeria; Hydrogeol. J. 16(3) 531-546.

Bajjali W 2006 Recharge mechanism and hydrochemistry evaluation of groundwater in the Nuaimeh area, Jordon, using environmental isotope technique; Hydrogeol. J. 14 180-191.

Barker M N and Horton R E 1936 Historical development of ideas regarding the origin of springs and groundwater; Trans. Am. Geophys. Union 17 395-400.

Bhat D K 1975 On the Quaternary geology of Kashmir Valley with special reference to stratigraphy and sedimentation; Geol. Surv. India Misc. Publ. 24(1) 188-203.

Bhat N A, Jeelani G and Bhat M Y 2014 Hydrogeochemical assessment of groundwater in karst environments, Bringi watershed, Kashmir Himalayas, India; Curr. Sci. 106(7) 1000-1007.

Chow V T, Maidment D R and Mays L W 1988 Applied Hydrology; McGraw-Hill, International Editions, Singapore.

Clark I D and Fritz P 1997 Environmental isotopes in hydrogeology; Lewis Publishers, Boca Raton.

Cook P G, Herczeg A L and McEvan K L 2001 Groundwater recharge and stream baseflow, Atherton Tableleands, Queensland; CSIRO Land Water, CSIRO, Clayton South, Australia, Technical Report 08/10.

Coward J M H, Waltham A C and Bowser R J 1972 Karst springs in the Vale of Kashmir; J. Hydrol. 16 213-223.

Craig H 1961 Isotopic variation in meteoric waters; Science 133 1702-1703.

Dansgaard W 1964 Stable isotopes in precipitation; Tellus 16 436-467.

Datta P S, Geol P S and Sangal S P 1973 Groundwater recharge in western Uttar Pradesh; Proc. Ind. Acad. Sci. 78(1A) 1-12.

Edmunds W M and Walton N R G 1980 A geochemical and isotopic approach to recharge evaluation in semi-arid zones: Past and Present; Arid-Zone Hydrology: Investigations with Isotope techniques, IAEA, Vienna, pp. 47-68.

Epstein S and Mayeda T 1953 Variation of $\delta^{18} \mathrm{O}$ content in waters from natural sources; Geochim. Cosmochim. Acta $4213-224$.

Eriksson E 1958 The possible use of Tritium for estimating groundwater storage; Tellus $10472-478$. 
Eriksson E and Khunakasem V 1969 Chloride concentration in groundwater, recharge rates and rate of deposition of Chloride in Israel Coastal Plain; J. Hydrol. 7 178-197.

Fetter C W 1980 Applied Hydrology; 2nd edn, Merrill, Columbus.

Ford D and Williams P 1989 Karst Geomorphology and Hydrology; London: Chapman and Hall.

Fredrickson G C and Criss R E 1999 Isotope hydrology and time constants of the unimpounded Meramec River basin, Missouri; Chem. Geol. 157 303-317.

Freeze R A and Cherry J A 1979 Groundwater; Prentice Hall, N.J.

Gat J R 1971 Comments on the stable isotope method in regional groundwater investigations; Water Resour. Res. 7 980-993.

Gat J R, Shemesh A, Tziperman E, Hecht A, Georgopoulos D and Ozden B 1996 The stable isotope composition of water of the eastern Mediterranean Sea; J. Geophys. Res. 101 6441-6451.

GSI 2012 Geology and mineral resources of Jammu \& Kashmir State; Geol. Surv. India Misc. Publ. 30, Part X.

Goldscheider N and Drew D 2007 Methods in Karst Hydrogeology; Taylor and Francis, London.

Gonfiantini R 1981 The $\delta$-notation and the mass spectrometric measurement techniques. Stable isotope hydrology, deuterium and oxygen in the water cycle; International Atomic Energy Agency, Vienna, Technical reports Series No. 210

Gonfiantini R, Gallo G, Payne B R and Taylor C B 1976 Environmental isotopes and hydrochemistry in groundwater of Gran Canaria; IAEA Staff, Editor, Interpretation of Environmental Isotope and Hydrochemical Data in Groundwater Hydrology, IAEA, Vienna, pp. 159-170.

Greene E A 1997 Tracing recharge from sinking streams over spatial dimensions of kilometers in a karst aquifer; Ground Water 35(5) 898-904.

Herczeg A I, Torgersen T, Chivas A R and Habermehl M A 1991 Geochemistry of groundwater from the great Artesian Basin, Australia; J. Hydrol. 126 225-245.

Houston J 1988 Rainfall-runoff relationships in the basement rock of Zimbabwe; In: Estimation of natural groundwater recharge (ed.) Simmers L, Riedel, Dordrecht, The Netherlands, pp. 349-365.

Hussain M 2005 Geography of Jammu and Kashmir; 4th edn, Rajesh Publications, New Delhi.

Jeelani G 2004 Effect of subsurface lithology on hydrochemistry of springs of a part of Kashmir Himalaya; Him. Geol. 25(2) 145-151.

Jeelani G 2007 Hydrogeology of hard rock aquifer in Kashmir valley: Complexities and uncertainties; In: Groundwater dynamics in hard rock aquifers - including sustainable management and optimal monitoring network design (eds) Ahmad S, Jayakumar R and Abdin S, Springer Verlag, Netherland, pp. 243-248.

Jeelani G 2008 Aquifer response to regional climate variability in a part of Kashmir Himalayas in India; Hydrogeol. J. 16 1625-1633.

Jeelani G, Bhat N A and Shivanna K 2010 Use of $\delta^{18} \mathrm{O}$ tracer to identify stream and spring origins of a mountainous catchment: A case study from Liddar watershed, western Himalaya, India; J. Hydrol. 393 257-264.
Jeelani G, Bhat N A, Shivanna K and Bhat M Y 2011 Geochemical characterization of surface water and spring water in SE Kashmir valley, western Himalayas: Implication to water-rock interaction; J. Earth Sys. Sci. 120(5) 921-932.

Jhonston C D 1987 Preferred water flow and localized recharge in a variable regolith; J. Hydrol. 94 129-142.

Kattan Z 1997 Environmental isotope study of the major karst springs in Damuscus limestone aquifer system: Case of the Figeh and Barada springs; J. Hydrol. 193 161-182.

Katz B G, Lee T M, Plummer L N and Busenberg E 1995 Chemical evolution of groundwater near a sinkhole lake, northern Florida: 1. Flow patterns, age of groundwater, and influence of lake water leakage; Water Resour. Res. 31(6) 1549-1564.

Katz B G, Coplen T B, Bullen T D and Davis J H 1997 Use of chemical and isotopic tracers and geochemical modeling to characterize the interactions between ground water and surface water in mantled karst; Ground Water $\mathbf{3 5 ( 6 )}$ 1014-1028.

Kendall C and Mcdonnell J J 1998 Isotope Tracers in Catchment Hydrology; Elsevier Science B.V., Amsterdam, pp. $1-50$.

Lang Y C, Liu C Q, Zhao Z Q, Li S L and Han G L 2006 Geochemistry of surface and ground water in Guiyang, China: Water/rock interaction and pollution in a karst hydrological system; Appl. Geochem. 21(6) 887903.

Longinelli A and Selmo E 2003 Isotopic composition of precipitation in Italy: A first overall map; J. Hydrol. 270 $75-88$.

Marfia A M, Krishnamurthy R V, Atekwana E A and Panton W F 2004 Isotopic and geochemical evolution of ground and surface waters in karst dominated geological setting: A case study from Belize, Central America; Appl. Geochem. 19 937-946.

Middlemiss C S 1910 A revision of Silurian-Triassic sequence of Kashmir; Rec. Geol. Surv. India 40(3) 6-260.

Mook W G 2006 Introduction to Isotope Hydrology; Taylor and Francis/Balkema, The Netherlands.

Moral F, Cruz-Sanjulian J J and Olias M 2008 Geochemical evolution of groundwater in the carbonate aquifers of Sierra de Segura (Betic Cordillera, southern Spain); J. Hydrol. 360 281-296.

Navada S V and Rao S M 1991 Study of Ganga Rivergroundwater interaction using environmental oxygen-18; Isotopenpraxis 27 380-384.

Necve A 1933 The tourist's guide to Kashmir, Ladakh, Skardu, etc.; Lahore.

Price R M, Swart P K and Willoughby H E 2008 Seasonal and spatial variation in the stable isotopic composition $\left(\mathrm{d}^{18} \mathrm{O}\right.$ and $\left.\mathrm{dD}\right)$ of precipitation in south Florida; J. Hydrol. 358 193-205.

Rao S M 2006 Practical Isotope Hydrology; New India Publishing Agency, New Delhi.

Rozanski K, Arugua's-Arugua's L and Ganfiantini R 1993 Isotopic patterns in modern global precipitation; Geophys. Mono. 78 1-36.

Sami K and Hughes D A 1996 A comparison of recharge estimates to a fractured sedimentary aquifer in South Africa from a chloride mass balance and an integrated surface and subsurface model; J. Hydrol. 179(1-4) 111-136. 
Sharma M L and Hughes M W 1985 Groundwater recharge estimation using chloride, deuterium and oxygen-18 profiles in the deep coastal sands of western Australia; $J$. Hydrol. 81 93-109.

Shivanna K, Kulkarni U P, Joseph T B and Navada S V 2004 Contribution of storms to groundwater recharge in the semi-arid region of Karnataka, India; Hydrol. Process. 18 473-485.

Sidle W C 1998 Environmental isotopes for resolution of hydrology problems; J. Environ. Mon. Assess. 52 389-410.

Vreča P, Bronić I K, Horvatinčić N and Barešić J 2006 Isotopic characteristics of precipitation in Slovenia and Croatia: Comparison of continental and maritime stations; J. Hydrol. 330 457-469.
Wadia D N 1975 Geology of India; Tata McGraw Hill, New Delhi.

Warrier C U, Babu M P, Manjula P, Velayudhan K T, Hameed A S and Vasu K 2010 Isotopic characterization of dual monsoon precipitation-evidence from Kerala, India; Curr. Sci. 98(11) 1487-1495.

Wood W W and Sanford W E 1995 Chemical and isotopic methods for quantifying groundwater recharge in a regional, semi-arid environment; Ground Water 33 458468.

Yurtsever Y and Gat J R 1981 Atmospheric waters; In: Stable isotope hydrology: Deuterium and oxygen-18 in water cycle (eds) Gat J R and Gonfiantini R, IAEA Technical Report Series 210 103-142.

Corresponding editor: RAJIB MAITY 